\title{
COCOA PROCESSING INDUSTRY FEASIBILITY ANALYSIS (CASE STUDY IN HOUSE OF CHOCOLATE DEPARTMENT OF INDUSTRY CENTRAL SULAWESI PROVINCE) IN PALU
}

\author{
Evyana Marwati Bangkele $^{I)}$, Made Antara ${ }^{2)}$, Lien Damayanti ${ }^{2)}$ \\ ${ }^{1)}$ Department of Industry and Trade. Central Sulawesi Province. \\ E-mail: Evyana_mb@yahoo.co.id \\ ${ }^{2)}$ Lecturer and Researcher at Department of Agribusiness Faculty of Agriculture. University of Tadulako. Palu.
}

\begin{abstract}
This study aims to determine the appropriateness of the establishment of cocoa processing industry (Rumah Coklat Office of Industry and Trade of Central Sulawesi Province) in Palu based on market aspects, technical aspects, aspects of the organization and management as well as financial aspects. The research was conducted in the city of Palu, namely Rumah Coklat Industry and Trade Office of Central Sulawesi province were carried out from July to September 2016. The method used was survey used data sourced from Rumah Coklat Department of Industry and Trade of Central Sulawesi province and institutions associated with the study and the results of research conducted by the Center for R \& D relating to the cacao processing. Data collected was processed and analyzed the aspects of the market, technical, organizational and management aspects and financial aspects. The results showed that the business of processing cocoa into chocolate and chocolate converture liqour from the aspect of the market is feasible to set up because it has a fairly large market opportunities, both domestic market and overseas markets. Based on a technical aspect, the business of processing cocoa into chocolate liqour and chocolate converture feasible to implement in Palu because of the availability of raw materials, labor, buildings and facilities equipment, the need for production machinery and equipment, the capacity of production capacity and the production process is relatively easy to be fulfilled and realized. Based on the aspect of organization and management, processing of chocolate is feasible. Because the needs of the labor management section and production section is obtained in accordance with the wishes of the company, as well as the maintenance of legality companies easily obtained. Financial aspects of the analysis results obtained by period of return on investment or payback period is 7 years. NPV is Rp. 182,141,428. IRR is about 14 and PI is $1.08 \%$. BEP amounted to $58.28 \%$ of total sales or Rp. $323,561,529$. as well as the results of the sensitivity analysis shows that this cocoa processing business into chocolate liquor and converture very sensitive to the price of raw materials cocoa and the amount of the sale. Based on the calculation and analysis can be concluded that the cocoa processing industry namely Rumah Coklat Office of Industry and Trade of the Province of Central Sulawesi in Palu meet the eligibility criteria and eligible to be run the business.
\end{abstract}

Key Words : Cacao, industry, market.

\section{INTRODUCTION}

Cocoa (Theobroma Cacao L.) is one of the commodities which has a role that is quite real and reliable in realizing agricultural development programs, particularly in terms of employment, drivers of regional development, improving the welfare of farmers and communities, as well as increased income/foreign exchange. Indonesia is the third largest cocoa producer in the world. Its production reached about 
600 thousand tons per year. Of that amount, 74 percent cocoa to be exported because it is not absorbed in the country. Most cocoa in Indonesia (around 96 percent) is produced by farmers (ASKINDO, 2011). In 2012 the Indonesian cocoa production increased, thus it becoming the $2^{\text {nd }}$ largest cocoa producerin the world, with production reaching 922720 tones, below Côte d'Ivoire/Ivory Coast Africa with a production of 1.38 million tons.

Central Sulawesi Cocoa Production in 2015 reached $208485256 \mathrm{~kg}$ with a total area of 291445 ha smallholder plantations spread over 13 districts in the city of Central Sulawesi, especially in the district of Parigi Moutong which has the largest cocoa production is about $33.6 \%$ of the total production of 208485 tones, followed by about $16.6 \%$ Poso district, Donggala about $11 \%$, district Sigi and Banggai about $10 \%$ and other districts (Kota Palu, North Morowali, Morowali, Buol, Tolitoli, and Tojo Unauna) of approximately $20 \%$.

Compared with Malaysia cocoa beans products amounted to only 60,000 tones per year, but is able to produce the cocoa processing of 300,000 tons per year. Additional supply of raw materials comes from Indonesia (including Central Sulawesi), and thus the added value of cocoa enjoyed by other States. For a future development is targeted in 2016 in which the central Sulawesi cocoa exports has been in the form of fermented cocoa, partly to supply cocoa processing industry in the country and partly to recycle themselves.

Cocoa has the prospect to be processed into a variety of products that have high added value such as the chocolate industry. There is now an industry engaged in processed chocolate, which is located in several District Municipality in Central Sulawesi, ranging from product cotton candy, chocolate candy, and chocolate bars that require raw materials chocolate (Chocolate Liquor and Couverture) to process into various processed products of chocolate.

The availability of raw materials from cocoa beans are still quite a lot and there is no similar industries engaged in the processing of cocoa beans to become chocolate, so it is very potential to establish a cocoa processing industry in Palu.

Based on the description it is an issue of concern in this study Is the establishment of cocoa processing industry in Palu is feasible, viewed from the aspect of the market, technical, organizational and management aspects, as well as the financial aspects?

The purpose of this study was to determine the appropriateness of the establishment of cocoa processing industry (House of Chocolate, Department of Industry and Trade of the Province of Central Sulawesi) in Palu based on market aspects, technical aspects, aspects of the organization and management, as well as financial aspects.

\section{METHODS}

The chosen area for this study is the city of Palu. The choice of location for research is due to the city of Palu as the capital of the Province, as well as distribution centers throughout the cocoa beans from cocoa-producing region, and also as a center for the development of the cocoa industry in Central Sulawesi. This research was conducted for three months ie from July to September 2015.

This study used field research techniques (survey) data collection, namely by conducting direct research in Industry ie House Chocolate-Cocoa Processing of Central Sulawesi Department of industry, located in Setia Budi street No.18 Palu.The analysis technique used in this study aims to test the feasibility of the business, starting from feasibility analysis of market and marketing aspects, technical aspects, and Technology, and Management of Organizational Aspects 
and Financial Aspects. To know the feasibility of each aspect of the feasibility of the cocoa processing industry Chocolate House Office of Industry and Trade of Central Sulawesi province with the following criteria:

Market and Marketing Aspects. For the feasibility of market and marketing aspects in the analysis are:

a. Potential Market

b. The market opportunity (the magnitude of the difference between bid and ask) to know the size of the market opportunity in business establishment cocoa processing plant is in use forecasting methods linear regression formula

$$
\mathrm{Y}=\mathrm{a}+\mathrm{bx}
$$

where:

$\mathrm{Y}=$ Variable needs of cocoa

$\mathrm{X}=$ Variable time, $\mathrm{a}$ and $\mathrm{b}$ parameter regression coefficient,

$$
\begin{aligned}
& \bar{X}=\frac{\sum \mathrm{X}}{n}, \\
& \bar{Y}=\frac{\sum \mathrm{Y}}{n}, \\
& \text { b }=\frac{\mathrm{n} \sum \mathrm{XY}-\sum \mathrm{X} \sum \mathrm{Y}}{\mathrm{n} \sum \mathrm{X}^{2}-\left(\sum \mathrm{X}\right)^{2}}, \\
& \mathrm{a}=\overline{\mathrm{Y}}-b \quad \overline{\mathrm{X}}_{y}
\end{aligned}
$$

c. Market Share

d. Marketing Strategy

Financial Aspects . For the feasibility of the financial aspects, which were analyzed were:

a. The need for investment costs,

b. the Working Capital Needs

c. Source-a source of funds to be obtained,

d. The Investment Assessment Criteria.

The methods used to analyze the financial feasibility, are as follows:

1) Method of Pay-Back period (PP)

2) Net Present Value (NPV)

3) Probability Index (PI)

4) Internal Rate Of Return (IRR)
5) analysis Break Even Point (BEP)

6) Sensitivity Analysis

\section{RESULTS AND DISCUSSION}

Markets and Marketing Aspects Analysis

Market Potential. Potential consumer chocolate factory owned by the industry are the small and medium enterprises which are also engaged in cocoa processing and using chocolate as the main raw material in the manufacture of their products.

Market Opportunities. Market opportunities describe how great the opportunity or possibility of the market to deliver the products to the consumers. Market opportunities seen through the approach of a request (demand) and supply.

Forecasting made with quantitative approach using linear regression (RL). Inanalysis linear regression variable is the time in the form of $\mathrm{Y}=\mathrm{f}(\mathrm{X})$, then $\mathrm{Y}$ is the variable that is predictable and $\mathrm{X}$ is the time variable.

Table 1. Data of the Numbers of Chocolate Industry Performers in County/City of 2011-2015

\begin{tabular}{clc}
\hline No & Regency / City & $\begin{array}{c}\text { Number of } \\
\text { SME (Unit) }\end{array}$ \\
\hline 1 & Palu & 30 \\
2 & Sigi & 10 \\
3 & Donggala & 5 \\
4 & Parimo & 5 \\
5 & Poso & 5 \\
6 & Tojo Una-una & 6 \\
\hline & Total & 61 \\
\hline
\end{tabular}

Source: Department of Industry, Central Sulawesi Province.

Table 2. Data of IKM Cocoa Needs or Requests Years 2011-2015

\begin{tabular}{cc}
\hline Year & Demand \\
\hline 2011 & 1.066 \\
2012 & 1.084 \\
2013 & 2.147 \\
2014 & 3.271 \\
2015 & 3.292 \\
\hline
\end{tabular}

Source: Department of Industry, Central Sulawesi Province. 
From the needs or requests Chocolate by SMEs data can be described as the following graph:

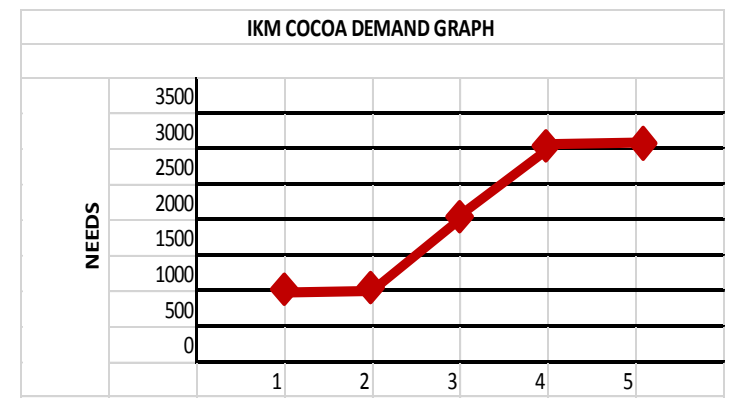

Figure 1: Graph requirement or request Year 20112015 SME chocolate

a. Demand projections

b. Projection Deals

Projection deals is the large supply of existing products in the market which are supplied by other manufacturers. Based on the data obtained from Department of Industry Central Sulawesi Province and of the perpetrators of SMEs chocolate that kind of chocolate is in use or currently use to create different types of chocolate products such as chocolate bars, chocolate Pralin, brownies, chocolate drinks Tri One and others are cocoa couverture, and liquor that use fat and cocoa beans native from Central Sulawesi. But it can't deny that the IKM chocolate also still use Compound Chocolate as an additive and flavor enhancer variations on various chocolate products such as chocolate brand collata, tulips, Van houten, Mercolade, Galetto and Flamboyan. The data about how many Compound chocolate products are in use by the SME chocolate business used are as follows:

Based on the table above the total number of deals in the SME chocolate brown in Central Sulawesi as much as $667 \mathrm{Kg}$. Offer is expected to increase by $5 \%$ per year on the assumption that the businesses in the sector has good prospects, so every year there will be new market participants or entrepreneurs engaged in cocoa processing. So the bidding for the beginning of the year 2017-2025 of chocolate compound product in the future can be seen in the following table:

$2016=($ Number of deals in 2015$)+($ Total offer 2015 x Percentage increase/ Year)

$2016=(667)+(667 x 0,005)$

$2016=667+3,335$

$2016=670$

Based on the table above, it can be seen that the market opportunity of a cocoa processing plant due to marketing the products of chocolate couverture and liquor to the SMEs chocolate in Central Sulawesi, has a very good opportunity because yet, there is no company or a chocolate factory in Central Sulawesi that produce fine chocolate couverture, liquor and compound.

\section{Market Share and The Sales Plan.} The market share is the amount of market opportunities or market share to be gained. As a newcomer, the determination of the market share is done by considering the demand and supply as well as the ability possessed by a company such as financial capacity, the ability of producing and selling skills. Here is the market share that is collected along with the sales plan that will be carried out as follows:

From the sales plan table, the market share is assumed as $85 \%$ of the amount, this consideration is taken based on the engine capacity and the capabilities of the company as new entrants such as financial capability in this case the ability to supply the raw materials.

Marketing and Strategy Program. The marketing strategy is a marketing plan that aims to outperform the competitor products that already exist. It is also the strategic steps that must be taken to maximal the market, some programs planned in marketing strategy to market chocolate products are as follows: 
Table 3. Forecasting Chocolate Products Inquiry Using Linear Regression Method, Year 2016-2025

\begin{tabular}{cccccr}
\hline Year & Level Requirement $Y$ & $X$ & $X^{2}$ & $Y^{2}$ & \multicolumn{1}{c}{$\mathrm{XY}$} \\
\hline 2011 & 1.066 & 0 & 0 & 1.135 .823 & 0 \\
2012 & 1.084 & 1 & 1 & 1.174 .189 & 1083,6 \\
2013 & 2.147 & 2 & 4 & 4.610 .683 & 4294,5 \\
2014 & 3.271 & 3 & 9 & 10.697 .806 & 9812,25 \\
2015 & 3.292 & 4 & 16 & 10.835 .618 & 13167 \\
\hline$\sum$ & 10.859 & 10 & 30 & 28.454 .118 & 28.357 \\
\hline
\end{tabular}

Description:

1) Value $\bar{X} \bar{X}$ and $\bar{Y} \bar{Y}$

$$
\begin{aligned}
& \bar{X}=\frac{\sum \mathrm{X}}{n}=\frac{\sum 10}{5}=1,666667 \\
& \bar{Y}=\frac{\sum \mathrm{Y}}{n}=\frac{\sum 10.859}{5}=2.172
\end{aligned}
$$

2).Value $b$ and value $a$ :

$$
\begin{aligned}
\mathrm{b} & =\frac{\mathrm{n} \sum \mathrm{XY}-\sum \mathrm{X} \sum \mathrm{Y}}{\mathrm{n} \sum \mathrm{X}^{2}-\left(\sum \mathrm{X}\right)^{2}} \\
& =\frac{(5 \times 28.357)-(10 \times 10.859)}{5 \sum 30-(10)^{2}} \\
& =664 \\
\mathrm{a} & =\overline{\mathrm{Y}}-b \overline{\mathrm{X}} \\
& =2.172-(664)(1,666667)
\end{aligned}
$$$$
=1.065
$$

Based on The Calculations Obtained Equation Y $=1,065+664 \mathrm{X}$,

Table 4. Data Deals Related Products 2016

\begin{tabular}{lc}
\hline \multicolumn{1}{c}{ Chocolate Brand } & Number of Products in Offer $(\mathrm{Kg})$ \\
\hline Chocolate Collata & 250 \\
Tulip & 87 \\
Van Houten & 120 \\
Mercolade & 150 \\
Galetto & 30 \\
\hline \multicolumn{2}{c}{ Total } \\
\hline
\end{tabular}

Source: Department of Industry Central Sulawesi Province.

Table: 5 Projected Number of Offer

\begin{tabular}{ccccc}
\hline Year & $\begin{array}{c}\text { Deals Related } \\
\text { Products (Kg/year) }\end{array}$ & $\begin{array}{c}\text { Growth Deals } \\
\text { Related Products }\end{array}$ & $\begin{array}{c}\text { Growth Rate } \\
\text { offer }\end{array}$ & $\begin{array}{c}\text { Projected Number of } \\
\text { Bids (Kg/Unit) }\end{array}$ \\
\hline 1 & 2 & 3 & $4=2 \times 3$ & $5=3+4$ \\
2016 & 670 & $0.5 \%$ & 3 & 674 \\
2017 & 674 & $0.5 \%$ & 3 & 677 \\
2018 & 677 & $0.5 \%$ & 3 & 680 \\
2019 & 680 & $0.5 \%$ & 3 & 684 \\
2020 & 684 & $0.5 \%$ & 3 & 687 \\
2021 & 687 & $0.5 \%$ & 3 & 691 \\
2022 & 691 & $0.5 \%$ & 3 & 694 \\
2023 & 694 & $0.5 \%$ & 3 & 694 \\
2024 & 698 & $0.5 \%$ & 3 & 701 \\
2025 & 701 & $0.5 \%$ & 4 & 705 \\
\hline
\end{tabular}

Source: Data Processing. 
Table 6. Market Opportunities Calculation

\begin{tabular}{cccc}
\hline In & Demand & Offer & Market Opportunities \\
\hline 2016 & 4.385 & 674 & 3.711 \\
2017 & 5.049 & 677 & 4.372 \\
2018 & 5.713 & 680 & 5.032 \\
2019 & 6.377 & 684 & 5.693 \\
2020 & 7.041 & 687 & 6.353 \\
2021 & 7.704 & 691 & 7.014 \\
2022 & 8.368 & 694 & 7.674 \\
2023 & 9.032 & 698 & 8.335 \\
2024 & 9.696 & 701 & 8.995 \\
2025 & 10.360 & 705 & 9.655 \\
\hline
\end{tabular}

Source: The Results of Data Processing.

Table 7. Calculation of Market Share and Sales Plan

\begin{tabular}{|c|c|c|c|c|c|c|c|c|}
\hline \multirow{5}{*}{ years } & \multirow[b]{3}{*}{ Market } & \multicolumn{3}{|c|}{ Market Share } & \multicolumn{3}{|c|}{ Market Plan } & \multirow[b]{3}{*}{ Total Sales } \\
\hline & & \multicolumn{3}{|c|}{$(\%)$} & \multicolumn{3}{|c|}{$(\mathrm{Kg})$} & \\
\hline & & Chocolate & chocolate & chocolate & chocolate & chocolate & chocolate & \\
\hline & Opportunity & Liquor & Couverture & Couverture & Liquor & Couverture & Couverture & Plan \\
\hline & & & ( Dark ) & ( Milk ) & & ( Dark ) & ( Milk ) & \\
\hline 2016 & 3711 & $5 \%$ & $10 \%$ & $70 \%$ & 189 & 371 & 2598 & 3155 \\
\hline 2017 & 4372 & $5 \%$ & $10 \%$ & $70 \%$ & 219 & 437 & 3060 & 3716 \\
\hline 2018 & 5032 & $5 \%$ & $10 \%$ & $70 \%$ & 252 & 503 & 3523 & 4277 \\
\hline 2019 & 5693 & $5 \%$ & $10 \%$ & $70 \%$ & 285 & 569 & 3985 & 4839 \\
\hline 2020 & 6353 & $5 \%$ & $10 \%$ & $70 \%$ & 318 & 635 & 4447 & 5400 \\
\hline 2021 & 7014 & $5 \%$ & $10 \%$ & $70 \%$ & 351 & 701 & 4910 & 5962 \\
\hline 2022 & 7674 & $5 \%$ & $10 \%$ & $70 \%$ & 384 & 767 & 5372 & 6523 \\
\hline 2023 & 8335 & $5 \%$ & $10 \%$ & $70 \%$ & 417 & 833 & 5834 & 7084 \\
\hline 2024 & 8995 & $5 \%$ & $10 \%$ & $70 \%$ & 450 & 900 & 6297 & 7646 \\
\hline 2025 & 9655 & $5 \%$ & $10 \%$ & $70 \%$ & 483 & 966 & 6759 & 8207 \\
\hline
\end{tabular}

Source: Results Data Processing.

a. Product

In accordance with the original purpose of the establishment of a chocolate factory, the type of products to be produced are three types of chocolate liquor, milk couverture chocolate and dark chocolate couverture. In order for production of the products that can compete in the market and can be in the interest of consumers, so some of the things need to be done in marketing the Chocolate products which is:

1) The Products of chocolate couverture and liquor are packed using aluminum foil packaging.

2) Net weight each package varies from $1 \mathrm{~kg}$ to $3 \mathrm{~kg}$
3) Attractive package and brand the product "Chocolate Sulteng"

4) Quality of products should be guaranteed is the best because it uses cocoa beans from Central Sulawesi, which has been in full fermented and processed using modern engine technology, each of chocolate products that used the raw materials of chocolate couverture and liquor, will make the chocolate products become more shiny, has a better taste and aroma.

b. Prices

In order to achieve maximum profit, it would require careful pricing strategies. In order to maximize sales, 
dominate the competition, and the opportunity to enter the broader market (market share), the couverture chocolate products (Dark and Milk) and liquor in the production will be marketed at prices ranging from Rp 160,000/kg.

c. Distribution

As a newcomer in the network for the distribution of products of chocolate couverture and chocolate liquor, the result of a production from The house of Chocolate does not use an intermediary, the consumers can buy or order directly at the place of production, it is more because the chocolate product is a kind of product that is easy contaminated with odor or other scents and can not stand at a certain temperature that exceeds the limit. Required a substantial investment to distribute these products as other products distributed.

d. Promotion

In order to introduce this product to the general public, especially the SMEs chocolate Central Sulawesi, the initial program is taken as a form of promotion that will do the company is to participate in events promotion provided by the Government of Central Sulawesi and the Ministry of Industry of the Republic of Indonesia. It is more effective and can minimize marketing costs.

\section{Financial Aspects}

Cost Investment Needs. Broadly speaking, the cost of the investment needs include pre-investment costs, the cost of fixed assets and operating costs. The cost data obtained from the investment needs of field surveys, store, market research, and interviews with interested parties. The required amount of investment costs in a feasibility study on The house of chocolate is at $\mathrm{Rp}$ 2.387.449.928, with details as follows: a. Cost of Pre - Investment

b. CostsTangible Fixed Assets

c. Production costs

1) The cost of purchasing raw materials and auxiliary materials for 1 year

2) Factory overhead expense An all expenses related to the activity of operating processes that occur in the plant. In this feasibility study, factory overhead costs include the cost of electricity and gas. The amount of overhead costs that will be issued in the first year the company is equal Rp. 30.000.000, where each year is assumed to cost increases by $5 \%$.

d. Operating expenses

1) Marketing costs

2) Labor Costs

3) General and administrative expenses

General and administrative expenses include the fees and charges for internet and office stationery. The amount of general and administrative expenses that the company will be issued each year is in the amount of Rp. 9,000,000.

4) Maintenance Costs

Maintenance costs include machinery and equipment, buildings and also the office equipment. The amount of maintenance costs that should be incurred every year is Rp. 15.600.000, every year it is assumed there is no increase.

5) Equipment Purchase Costs

In this chocolate industry, the economic life of certain types of equipment used are insufficient with business economic life (10 years), each year should be held back a number of equipment to purchases. As for the cost of equipment purchases each year which must be issued by the company amounted to Rp 3.85 million with the assumption that every year the numbers has to rise by $2 \%$. 
Table 8. Pre-Investment Cost

\begin{tabular}{clr}
\hline No & \multicolumn{1}{c}{ Group Fees } & \multicolumn{1}{c}{$(\mathrm{Rp})$} \\
\hline 1 & Development Studies Cost & $15,000,000$ \\
2 & Handling License-permit Cost & $5,000,000$ \\
3 & Survey Cost & $10,000,000$ \\
4 & Experiment Production Costs & $20,000,000$ \\
5 & Initial Campaign Costs & $10,000,000$ \\
\hline \multicolumn{1}{c}{ Total Costs } & $60,000,000$ \\
\hline
\end{tabular}

Table 9. Tangible Fixed Assets Cost

\begin{tabular}{|c|c|c|c|c|}
\hline No & Group Fees & Amount & Price (Rp) & Total Cost ( Rp ) \\
\hline 1 & Location & & & 500000000 \\
\hline 2 & Building & & & 750000000 \\
\hline \multirow[t]{8}{*}{3} & Machine & & & \\
\hline & 1. Roasting & 1 Unit & 180000000 & 180000000 \\
\hline & 2. Crusher & 1 Unit & 175000000 & 175000000 \\
\hline & 3. Stone Milling & 1 Unit & 140000000 & 140000000 \\
\hline & 4. Ballmilling & 2 Unit & 185000000 & 370000000 \\
\hline & 5. Storage Tank & 1 Unit & 35000000 & 35000000 \\
\hline & 6. Conching Temper & 1 Unit & 75000000 & 75000000 \\
\hline & 7. Sofkes & 3 Unit & 8500000 & 25500000 \\
\hline \multirow[t]{11}{*}{4} & Equipment & & & \\
\hline & Chocolate Molds & 20 Dozen & 120000 & 2400000 \\
\hline & Chamfer & 20 Dozen & 20000 & 400000 \\
\hline & Basin & 10 Pieces & 75000 & 750000 \\
\hline & Spoon & 5 Dozen & 25000 & 125000 \\
\hline & Spatula & 5 Dozen & 25000 & 125000 \\
\hline & Digital Scales & 2 Pieces & 250000 & 500000 \\
\hline & Manual Scales & 1 Pieces & 150000 & 150000 \\
\hline & Hand Stiller & 1 Pieces & 300000 & 300000 \\
\hline & Window Display Cabinet & 1 Pieces & 3000000 & 3000000 \\
\hline & Thermometer & 2 Pieces & 150000 & 300000 \\
\hline \multirow[t]{7}{*}{5} & Office Inventory & & & \\
\hline & Computer & 1 Unit & 5000000 & 5000000 \\
\hline & Table & 6 Unit & 6000000 & 36000000 \\
\hline & Chairs & 8 Unit & 350000 & 2800000 \\
\hline & Cabinet & 3 Unit & 1500000 & 4500000 \\
\hline & Air Conditioner & 3 Unit & 5000000 & 15000000 \\
\hline & Printer & 1 Unit & 3000000 & 3000000 \\
\hline 6 & Others & & & 2000000 \\
\hline
\end{tabular}

Source: House of Chocolate.

Table 10. Cost of Raw Materials and Helper for 1

\begin{tabular}{clcccr}
\hline No & \multicolumn{1}{c}{ Details } & Needs & Unit & Unit Price (Rp) & Amount (Rp) \\
\hline 1 & fermented cocoa beans & 1643 & $\mathrm{Kg}$ & 40000 & 65.725 .057 \\
2 & sugar & 150 & $\mathrm{Kg}$ & 12000 & 6.123 .452 \\
3 & chocolate fat & 572 & $\mathrm{Kg}$ & 120000 & 68.582 .668 \\
4 & milk powder & 829 & $\mathrm{Kg}$ & 75000 & 62.153 .043 \\
5 & Lecithin & 10 & Liter & 75000 & 750.000 \\
7 & Salt & 5 & packs & 50000 & 1.500 .000 \\
\hline & & & & 205.609 .220
\end{tabular}

Source: House of Chocolate. 
Table 11. Marketing Costs for 1 Year

\begin{tabular}{cccc}
\hline No & Cost Type & Requirement Per Month (RM) & Requirement Per Year (USD) \\
\hline 1 & Packaging Costs & 763698 & $9,164,378$ \\
2 & Promotion Costs & $3,000,000$ \\
\hline \multicolumn{3}{c}{ Total Costs } & $12,164,378$ \\
\hline
\end{tabular}

Table 12. Labor Cost

\begin{tabular}{clccc}
\hline No. & \multicolumn{1}{c}{ Position } & Total & $\begin{array}{c}\text { Month Salary } \\
\text { Cost }\end{array}$ & $\begin{array}{c}\text { Total Cost Salary 1 } \\
\text { Year }\end{array}$ \\
\hline 1 & Manager & 1 & $2,000,000$ & $24,000,000$ \\
2 & Administrative \& General & 1 & $1,250,000$ & $15,000,000$ \\
3 & Marketing & 2 & $1,250,000$ & $30,000,000$ \\
4 & Production & 4 & 1500.000 & $72,000,000$ \\
\hline & Total & 8 & $6,000,000$ & 141000000 \\
\hline
\end{tabular}

Working Capital Needs. Costs or funds needed to finance various operational activities within the company. Once the process plant construction is completed, expected within the normal operating period (one year) cash increase can be achieved. The detailed list of working capital requirements in the establishment of a cocoa processing plant are as follows :

Obtained Sources of Funding. Source of funds that will be used in the construction of this plant comes from APBD (Regional Budget) Department of Industry and Trade of Central Sulawesi province, as well as from the state budget of the Republic of Indonesia through the Ministry of Industry Director General of Agro, ie with a total investment amount of Rp. 2.387.449.928, where 58\% is taken from the budget of the Department of Trade and Industry Central Sulawesi and $42 \%$ is obtained from the Director General of the Ministry of Agro Industry of the Republic of Indonesia.

Estimatedincome. The amount of revenue each year is determined by the amount of sales targets and the company's ability to produce. Total revenue and total production each year is always fluctuating, it is adjusted to the target amount of sales made by the company and the products selling price of that are marketed, where the selling price of all three of chocolate products is Rp. 160,000. More specifically, of the income earned each year can be seen in the following table :

Depreciation and Amortization. When an asset-fixed (building, machinery, equipment, and other supplies) are used in a company's activities, the longer it will decrease productivity capabilities. therefore the price (value) of the assets would be even smaller. In this case the company to calculate the cost of depreciation and amortization using the Straight Line Method (SLM) or straightline method. The amount of depreciation costs derived from the calculation amounted Rp. 6.2.877.500 and amortization costs amounted Rp. 9.000.000.

\section{Financial Statements.}

a. Income Projection

In the income / loss, in the first year net profit after tax was Rp.13.945.725 with selling price Rp.160.000 / kg for all types of chocolate products.

b. Cash Flow

Cash flow is the amount of money in and out within an enterprise, ranging from investments made until the end of the investment. In the calculation of cash flows, cash obtained early (initial cash flow) in the first year is equal to Rp.2.353.250.000 the amount 
of net cash operation (Operation Cash flow) and the number of year-end cash (Terminal Cash flow) in the first year value is the same, namely by Rp. 85.823.225 it is due to the lack of credit payments of the investments.

c. Balance Projection

Balance is a financial statement that shows the position of assets, debts, and the company's capital at any given moment. all assets related to property owned by the company either in the form of current assets, fixed and not fixed assets. While the liabilities is an explanation of the obligations of the company and also the capital that owned by the company. Assets and liabilities should be in a balanced or equal position (balanced check). From the calculations, the total assets and liabilities in the first year amounted Rp. 2.353.250.000.

\section{Corporate Finance Feasibility Assessment (Financial).}

a. Net Present Value (NPV)

Investment feasibility assessment using the Net Present Value (NPV) is obtained by finding the difference between the current value of investment with the present value of net cash receipts in the future. The NPV with the discount factor $(r)=10 \%$ for 10 years showed a positive number that is equal to Rp.182.141.428,- then the establishment of a chocolate factory in Palu is eligible based on the economic considerations.

b. Profitability Index (PI)

Probability Index technique salso called the analysis techniques of the benefit cost ratio ( $\mathrm{B} / \mathrm{C}$ ratio). In this technique, to measure the appropriateness of a proposed investment project, is enough to compare between present value of the project's cash flow with present value (initial investment). If the PI is greater than 1, then the project proposal will be declared as feasible, but on the contrary if the PI is less than 1 then the project proposal will be declared as unfit.

Total Present Value (PV) : Rp 2.569.591.356

Early Investment $\quad:$ Rp 2.387.449.928

$$
\begin{array}{ll}
\text { PI } & =\frac{\operatorname{Rp} 2.569 .591 .356}{\operatorname{Rp} 2.387 .449 .928} \\
\text { PI } & =1,08
\end{array}
$$

Based on the calculation, the value of PI amounted to $1.08>1$, then the establishment of Chocolates factories in Palu declared as eligible to run.

c. Internal Rate of Return (IRR)

Internal Rate of Return (IRR) is a tool to measure the internal rate of return of the results of the company. If the IRR is greater than the value of lending companies, the business establishment will be declared as Decent, but on the contrary, if the value of IRR is less than the amount of credit interest, the business activities will be declared as unfit. Based on the results of the calculation of the Internal Rate Of Return (IRR) found that the results obtained are greater than the benefits required at $14 \%>10 \%$, then the project is the establishment of a chocolate factory should be feasible.

d. Payback Period (PP)

The payback period is an engineering assessment of the length of time (period) of the return on investment of a project or venture. The shorter the time from a payback period it will be the smaller the investment risk faced by investors, it will further attract the investors to invest in a project or venture. Based on calculations obtained from the Payback Period (PP) ie 7 years and 2 months 6 days shorter than the standard time of the economic life of the project is specified the Industry business processing cocoa in Palu declared eligible to run, which means that within 7 years 2 months 6 days all funds invested in the project is expected to be readmitted, hereinafter all of the net 
cash flow expected after this time will be a net gain for the company.

e. Break Even Point Analysis (BEP)

Break Even Point (BEP) Analysis is a break-even point where a project is in a position not to suffer losses and also not provide benefits. So to make a profit, product sells should be able to surpass the break-even point. Break Even Point Analysis (BEP) is used to estimate how much the minimum numbers that should be in production by the company and then sell their products in order not to suffer loss or experiencing Break Even Point. From the calculations result can be seen that the break-even point (BEP Q) of the companies in the first year can be achieved if the company sold as many as $3,470 \mathrm{~kg}$ of chocolate products and BEP is Rp. 323561529. The calculation that more details can be found in appendix.

f. A sensitivity analysis

This analysis seeks to provide an overview of the influence of various parameters against the feasibility of the business. The parameters are include: changes in selling prices, variable costs changes and market share changes.

Table 13. Working Capital Requirement

\begin{tabular}{|c|c|c|}
\hline No & Group Fees & Total Amount (Rp) \\
\hline A & Production Fees & \\
\hline 1 & Raw And Auxiliary Materials Purchase Costs & 204.859.220 \\
\hline \multirow[t]{2}{*}{2} & Factory Overhead Cost & 30.000 .000 \\
\hline & Sub Total & 234.859.220 \\
\hline $\mathrm{B}$ & Business costs & \\
\hline 1 & marketing costs & 9.939 .913 \\
\hline 2 & Labor & 141.000 .000 \\
\hline 3 & general and administrative expenses & 9.000 .000 \\
\hline \multirow[t]{4}{*}{4} & buildings and office equipment maintenance & 15.600 .000 \\
\hline & Sub Total & 175.539 .913 \\
\hline & Working Capital Requirements (1 year) $\mathrm{A}+\mathrm{B}$ & 410.399 .133 \\
\hline & Working Capital Requirements Per Period (Months) & 34.199 .928 \\
\hline
\end{tabular}

Table 14. Estimated Revenue

\begin{tabular}{|c|c|c|c|c|}
\hline \multirow{4}{*}{ year } & \multicolumn{3}{|c|}{ types of Products } & \multirow{4}{*}{ Total (Rp) } \\
\hline & Chocolate & Chocolate & Chocolate & \\
\hline & \multirow[t]{2}{*}{ Liquor } & Couverture & Couverture & \\
\hline & & (Dark) & (Milk) & \\
\hline 2016 & 29689467 & 59378933 & 415652532 & 504720932 \\
\hline 2017 & 34973839 & 69947678 & 489633748 & 594555265 \\
\hline 2018 & 40258077 & 80516154 & 563613077 & 684387308 \\
\hline 2019 & 45542179 & 91084359 & 637590510 & 774217048 \\
\hline 2020 & 50826149 & 101652291 & 711566039 & 864044479 \\
\hline 2021 & 56109975 & 112219950 & 785539652 & 953869577 \\
\hline 2022 & 61393667 & 122787334 & 859511341 & 1043692342 \\
\hline 2023 & 66677221 & 133354442 & 933481096 & 1133512759 \\
\hline 2024 & 71960636 & 143921173 & 1007448908 & 1223330717 \\
\hline 2025 & 77243912 & 154487824 & 1081414766 & 1313146502 \\
\hline
\end{tabular}

Source: Data Processing 
Table 15. Sensitivity Analysis

\begin{tabular}{|l|c|c|c|c|c|}
\hline \multicolumn{1}{|c|}{ analysis } & PP (years) & Averages BEP & NVP (Rp) & IRR (\%) & PI \\
\hline expected conditions & $\begin{array}{c}7 \text { years } 2 \text { month } \\
6 \text { days }\end{array}$ & $\begin{array}{c}1.513 \mathrm{Kg} \\
\mathrm{Rp} 242.057 .815\end{array}$ & 182.141 .428 & 14 & 1,08 \\
\hline selling prices decreased $0,47 \%$ & $\begin{array}{c}7 \text { years } 2 \text { month } \\
7 \text { days }\end{array}$ & $\begin{array}{c}1.531 \mathrm{Kg} \\
\mathrm{Rp} 243.866 .796\end{array}$ & 165.030 .358 & 15 & 1,07 \\
\hline variable cost increases $0,47 \%$ & $\begin{array}{c}7 \text { years } 2 \text { month } \\
7 \text { days }\end{array}$ & $\begin{array}{c}1.520 \mathrm{Kg} \\
\mathrm{Rp} 243.198 .487\end{array}$ & 168.310 .677 & 14 & 1,07 \\
\hline market share decline $0,47 \%$ & $\begin{array}{c}7 \text { years, 3 month } \\
8 \text { days }\end{array}$ & $\begin{array}{c}1.526 \mathrm{Kg} \\
\mathrm{Rp} 244.145 .916\end{array}$ & 153.329 .903 & 16 & 1,06 \\
\hline
\end{tabular}

The Parameters Increase Determines Based on the Consumer Price Index (CPI) in Palu, Prevailing by $0.47 \%$.

\section{CONCLUSIONS AND RECOMMENDATIONS}

\section{Conclusions}

1. Analysis of Business stated that chocolate processing plant was declared feasible, as in the know that the level of SME needs chocolate products each year will always increase. the amount of the price of chocolate products offered by the company is $\mathrm{Rp} 160,000 / \mathrm{kg}$, where the price is still below the average market price.

2. Technological and Technical Aspects

Based on the analysis of the technical aspects, it can be concluded that the business of chocolate processing plant is feasible. This can be seen in terms of availability of raw material, labor, equipment buildings and facilities, production machinery and equipment needs, the capacity of the production capacity and the production process is relatively easy fulfilled and realized.

3. Management and Organization Aspects

Judging from the organization and management aspect, as well as based on the results of the analysis it can be concluded that the business of chocolate processing plant is feasible. The needs against labor is in accordance with the wishes good company management section and production section is easy to obtain, as well as the maintenance of legality companies easily obtained.

4. Financial aspects

Judging from the financial aspects, efforts chocolate processing plant is feasible. It can be seen from some of the parameters of the feasibility assessment for investment, including:

a. NPV $>0$, amounted Rp. 182.141.428 which means that the business of cocoa processing plants is feasible, where the NPV value indicates a benefit or a net income, received during the economic life of the project on the level of discount (discount factor) that applies (10\%).

b. IRR obtained from financial analysis is $14 \%$ where the IRR is greater than discount factor which is $10 \%$ applicable. The IRR value indicates the level of internal projects at $14 \%$ and for IRR> $10 \%$, then this business is feasible and profitable.

c. Profitability Index (PI) obtained value is 1.08 which states that businesses of cocoa processing plant is feasible. Profitability value equal to the index of 1.08 means that every RP 1 costs incurred over the life of the project resulted in a net benefit of 1.08 units.

d. Payback Period (PP) has a payback investment costs period it is for 7 years, 4 months, 11 days

e. Breakeven point (BEP) in the first year as many as $2,022 \mathrm{~kg}$ or Rp. 323.561.529. Thus, the effort is feasible because it would be profitable 
for the owners of the investors or owners of capital.

f. the sensitivity analysis

From the results of the sensitivity analysis shows that all parameters compared to the base case, It produce a positive value. Thus, the effort is feasible.

\section{Recommendations}

The management of the Chocolate House should use the standard of feasibility which had and stated positive results, the eligibility can be used in carrying out the operational activity and gains more significant profit for the company.
In order for a cocoa processing business can be run well, the cooperation between relevant agencies such as the Department of Trade and Industry and the Department of Plantations ere needed. It aims to maintain the quality of the raw material for the chocolate production.

The House of Chocolate company should always pay attention and control so that volume of sales did not decline, this can be done by doing collaboration with chocolate SME associations and others groups as well as doing promotions so that the chocolate products is well known by the people in Central Sulawesi and also from outside the city.

\section{REFERENCES}

Dinas Perindustrian dan Perdangangan Provinsi Sulawesi Tengah, 2015. Data IKM Cokelat.

Dinas Perkebunan Provinsi Sulawesi Tengah, 2013. Laporan Perkembangan Produksi Tanaman Kakao di Provinsi Sulawesi Tengah. Palu. Sulawesi Tengah.

Dinas Perkebunan Provinsi Sulawesi Tengah, 2015. Laporan Perkembangan Produksi Tanaman Kakao di Provinsi Sulawesi Tengah. Palu. Sulawesi Tengah.

Jasman,p, 2004. Perkakaoan Indonesia. Makalah Simposium Kakao 2004, Tanggal 4-5 Oktober 2004 di Yogyakarta. Penyelenggara : Pusat Penelitian Kopi dan Kakao Indonesia. Jember.

Kasmir dan Jaktar, 2006. Studi Kelayakan Bisnis. Penerbit : Kencana Prenada Media Group. Jakarta.

Martono dan hardjito, 2005. Manajemen Keuangan. Penerbit : Ekonosia. Yogyakarta.

Mulato,S., Widyomoto, Misnawi, dan Suharyanti, 2005. Pengolahan Produk Primer dan Sekunder Kakao”. Pusat Penelitian Kopi dan Kakao Indonesia. Jember.

Said, E.G. dan Intan, 2004. Manajemen Agribisnis, Cetakan Kedua. Penerbit : Ghalia Indonesia. Jakarta.

Semaoen, I., 2000. Pengantar Menuju Agribisnis, Cetakan Ketiga. Penerbit : Gadjah Mada University Press. Yogyakarta.

Sikumbang. Z, Antonius P dan Madang S.M, 2004. Prospek Pengembangan Industri dan Ekspor Hasil Olahan Kakao Indonesia. Makalah yang disampaikan pada Simposium Kakao 2004, tanggal 4-5 Oktober 2004 di Yogyakarta. Penyelenggara : Pusat Penelitian Kopi dan Kakao Indonesia. Jember.

Soekartawi, 2005. Agribisnis, Teori dan Aplikasinya. Penerbit : PT. Raja Grafindo Persada. Jakarta.

Sudibyo, A.,Hartisari, H. Dan Arbaimah, 1999. Model Perecanaan Pengembangan Industri Kakao di Indonesia. Warta IHP. Volume 16 (1-2): 10-19

Sumardjo,J.S., dan Darmono, 2004. Teori dan Praktek Kemitraan Agribisnis, Cetakan Pertama”. Penerbit : Swadaya. Jakarta.

Susanto, FV, 1994. Tanaman Kakao. Penerbit : Kanisius. Yogyakarta. 
Sustrisno, 2003. Manajemen Keuangan, Teori, Konsep dan Aplikasi, Edisi Pertama Cetakan Ketiga. Penerbit : Ekonisia. Yogyakarta.

Tadjo, M., 2004. Dampak Agribisnis Kakao Terhadap Perekonomian dan Pendapatan Asli Daerah Sulawesi Selatan. Makalah yang disampaikan pada Simposium Kakao 2004, tanggal 4-5 oktober 2004 di Yogyakarta. Penyelenggara : Pusat Penelitian Kopi dan Kakao Indonesia. Jember.

Tjakrawedaya, Subiyakto, 1999. Pengantar Menuju Agribisnis, Cetakam Kelima. Penerbit : Universitas Gadjah Mada. Yogyakarta.

Umar, H. 2003. Studi Kelayakan Bisnis, Edisi Kedua. Penerbit : Gramedia Pustakan Utama. Jakarta.

Widyatomo, S dan Mulato, 2004. Rekayasa Proses dan Alat Mesin Pengolahan Produk Hilir Kakao untuk Skala Kecil Menengah. Makalah yang disampaikan pada Simposium Kakao 2004, tanggal 4-5 Oktober 2004 di Yogyakarta. Penyelenggara : Pusat Penelitian Kopi dan Kakao Indonesia. Jember.

Winadri, Benny, 2006. Menciptakan Jiwa Kewirausahaan. Penerbit : Graha Ilmu UIEU. Jakarta

Zubir, Z. 2006. Studi Kelayakam Usaha. Penerbit : Lembaga Penerbit Fakultas Universitas Indonesia. Jakarta. 